SCHWERPUNKT

\section{Challenges and Perspectives of Microalgae Production}

\section{Introduction to the Thematic Focus}

\author{
by Christine Rösch, ITAS, and Clemens \\ Posten, BLT (both KIT)
}

\begin{abstract}
Microalgae offer great promise to contribute to the future supply of biofuels, but great efforts in research, development and demonstration are needed to overcome the biological, technical, economic and environmental challenges to developing a sustainable and commercially viable microalgae production system. The thematic focus of this issue highlights the grand challenges, perspectives and milestones of microalgal biomass production. These articles provide an overview of the most important questions addressed by society, and the answers they offer contribute to our conceptual knowledge. They provide a basis on which we can undertake the first steps in assessing any unintended side-effects - a core business of technology assessment. ${ }^{1}$
\end{abstract}

\section{The Great Green Hope}

Microalgae are viewed with great hope by biomass producers. The hope is that microalgae will be able to overcome the obstacles encountered by first- and second-generation biofuels derived from biomass grown on arable land. They use sunlight five times more efficiently than terrestrial plants, can double their biomass in less than one day, and accumulate a high quantity of lipids, namely up to $50 \%$ of their ash-free cell dry weight (Tredici 2010). Optimistic theoretical estimates are in the range of 24,000 to 137,000 liters oil per ha and year depending on the strain's genetics, the growth method, access to key nutrients, and location (Chisti 2007; Rodolfi et al.
2009). Rapeseed - the dominant feedstock for biofuels in Germany - yields only between 1,200 and 1,600 liters per ha and year (TFZ Bayern 2012). The commercial algae production of Chlorella in Germany (Klötze) yields 80 to 100 t dry biomass per year, grown in tubular photobioreactors under mixotrophic conditions.

Microalgae can utilize a wide variety of water types, such as fresh, brackish, saline, marine, and waste water, and can be cultivated on otherwise non-productive, non-arable land. Besides, they can recycle $\mathrm{CO}_{2}$ and other nutrient waste streams and produce valuable coproducts in addition to biofuels (Benemann 1997). The development of technology for large-scale production and for supplying low-price bulk markets is still in its infancy, and strong and long-lasting efforts are needed in research, development, and demonstration to achieve the required progress. This issue of TATuP contributes to identifying the challenges that will likely need to be surmounted for microalgae to be used in the production of economically viable, environmentally sound biofuels. It is intended to serve as a resource for researchers, engineers, decision makers, and stakeholders by providing a summary of the current challenges and perspectives and indicating the direction that future activities in research, development, and demonstration should take.

\section{Wild Strain or Designer Algae?}

The selection of the appropriate strains of algae is an important factor in the overall success of the microalgal industry and of biofuel production. The natural variety of algae is enormous and represents an almost untapped resource. Current estimates indicate that there are more than 100,000 species which have not yet been described and which belong to several completely different biological groups. Depending on the species, they can accumulate different metabolites, such as lipids, hydrocarbons, vitamins, omega-3 fatty acids, pigments, antioxidants, and sterols. The main species used commercially are Chlorella and Spirulina for health food production, Dunaliella salina for $\beta$-carotene production, Haematococcus pluvialis for astaxanthin production, and several other species for aquaculture feed (Borowitzka 1999). One 
of the key challenges facing the production of algal biofuels is to find or develop species of algae that feature the following attributes at the same time:

- high photoconversion efficiency, rapid and stable growth

- high contents of lipids and valuable coproducts

- high $\mathrm{CO}_{2}$ absorbing capacity and limited nutrient requirements

- robustness towards shear stresses in photobioreactors and competitiveness against wild native strains in open ponds

- tolerance to temperature variations resulting from the diurnal cycle and seasons

- capability for live extraction ("milking") of valuable secondary metabolites

- self-flocculation ability

Worldwide screening of algae has resulted in a collection of over 3,000 strains with promising oil-producing features (Sheehan et al. 1998). The drawback of these strains is that they do not grow fast enough. Genetic and metabolic engineering can increase a species' ability to produce lipids and to achieve the processing capabilities needed (see fig. 1). Increasing the cellular lipid content, with an emphasis on triacylglycerols for the production of biofuels, is at the focus (Schuhmann et al. 2012).

More than 30 different strains of microalgae have been transformed successfully to date, raising encouraging prospects for creating designer algae that exhibit desired features (Radakovits

Fig. 1: Genetic engineering of microalgae

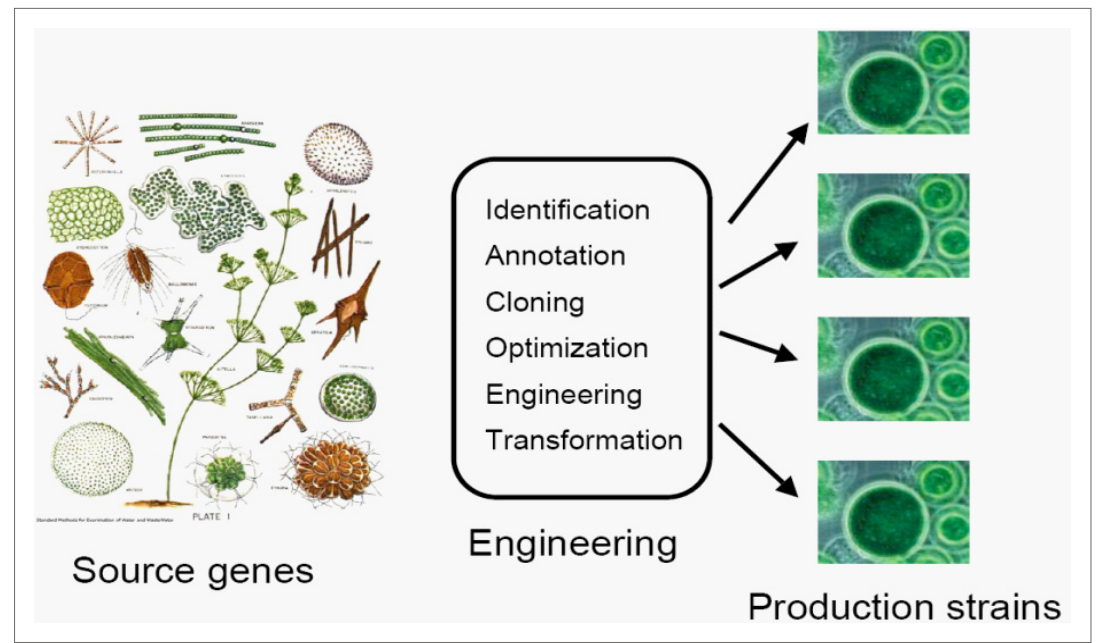

Source: Own compilation et al. 2010). Despite these promising concepts and successes, the development and distribution of superior designer algae will take some time because work on genetically modified algae is confined to a handful of private sector labs and a few academic institutions. While photosynthesis as such cannot be improved, targets of work are peripheral molecular structures such as antenna pigments, product profiles or metabolic overflow pathways. In this issue, Christian Wilhelm presents an approach for increasing microalgal biomass production and its energy efficiency. The concept of new green chemistry intends to reduce the number of conversion steps and metabolic processes needed to allocate the carbon into the macromolecular pools of the cell.

\section{Open Ponds or Photobioreactors?}

Most of the commercial systems employed for microalgae cultivation are artificial open ponds because they are cheap to build and easy to operate and scale up. So-called raceway ponds, usually lined with plastic or cement, are about 20 to $35 \mathrm{~cm}$ deep to ensure adequate exposure to sunlight. Paddlewheels provide motive force and keep the algae suspended in the water. The ponds are supplied with water and nutrients, and mature algae are continuously removed at one end. The main drawback of ponds is their biomass yield, which is in the range of 10 to $25 \mathrm{~g} /\left(\mathrm{m}^{2} \mathrm{~d}\right)$, and thus higher than for oilseed rape ( 0.8 to $1.6 \mathrm{~g} /$ $\left(\mathrm{m}^{2} \mathrm{~d}\right)$ ), but significantly lower than for microalgae grown in closed reactors (25 to $50 \mathrm{~g} /\left(\mathrm{m}^{2} \mathrm{~d}\right)$ ). Furthermore, the number of species which can be grown in ponds is limited, they are very vulnerable to contamination, and evaporative water loss. An overview of the differences between algae cultivation in ponds and reactors is given in table 1. Details of the design and operation 
of reactors can be found in the article by Clemens Posten in this issue.

Table 1: Comparison between algae cultivation in open ponds and photobioreactors

\begin{tabular}{|c|c|c|}
\hline Parameter & Open ponds & Photobioreactors \\
\hline Land footprint & High & Low \\
\hline Water footprint & High & Low \\
\hline $\mathrm{CO}_{2}$ release & High & Low \\
\hline $\begin{array}{l}\text { Energy re- } \\
\text { quirement }\end{array}$ & Low & High \\
\hline $\begin{array}{l}\text { Application of } \\
\text { waste water }\end{array}$ & Yes & Yes \\
\hline $\begin{array}{l}\text { Temperature } \\
\text { control }\end{array}$ & Not needed & Required \\
\hline $\begin{array}{l}\text { Reactor clean- } \\
\text { ing }\end{array}$ & Not needed & Required \\
\hline $\begin{array}{l}\text { Risk of con- } \\
\text { tamination }\end{array}$ & High & Low \\
\hline Product quality & Variable & Reproducible \\
\hline $\begin{array}{l}\text { Microbiology } \\
\text { safety }\end{array}$ & No & Yes \\
\hline $\begin{array}{l}\text { Biomass } \\
\text { productivity }\end{array}$ & Low & High \\
\hline $\begin{array}{l}\text { Capital and } \\
\text { operation costs }\end{array}$ & Low & High \\
\hline
\end{tabular}

Source: Own compilation

Of the different types of photobioreactors which have been developed so far, only the tubular reactor is used commercially. The hurdles to using photobioreactors for the mass production of biofuels are high capital and operation costs and the excessive demand for energy for pumping and the mixing of the culture medium and the harvesting process. Innovative photobioreactor concepts with a reduced energy demand, higher biomass concentration, and lower production costs can be expected in the future (Morweiser et al. 2010). Niels-Henrik Norsker and colleagues illustrate in this issue that positive net energy production and low production costs could theoretically be made feasible by changes in reactor design and operation. They point out that optimization of the reactor design will remain a trial-and-error process until the functional relationships between production factors and biomass productivity have been investigated. Clemens Posten alerts us to the fact in his article that other factors - apart from energy balance and maximum production - need to be opti- mized, such as geometric and hydrodynamic parameters, measured performance criteria, the mode and stability of operation, and cost effectiveness of the bioreactor. He presents several reactor designs with the objective of establishing a framework for the design and performance of photobioreactors.

\section{What is the Best Method for Harvesting and Dewatering?}

The harvesting and dewatering of small algal species in dilute suspensions at concentrations between less than $1 \mathrm{~g} / \mathrm{L}$ (ponds) and 3-15 g/L (photobioreactors) are difficult as well as energy intensive. Dewatering to about 20-30 \% water content is necessary in order to reduce volume and weight, to minimize transportation and downstream costs and to extend the shelf-life of the microalgae concentrate. Dewatering can be achieved using different physical, chemical, and biological methods depending on the type of algae, the requirements of the downstream processes, and the desired product quality. The techniques applied include flocculation, gravity sedimentation, centrifugation, filtration, and drying.

Autoflocculation and flocculation with alum, ferric chloride, chitosan, or hydrophobic absorbents (see fig. 2) and collection by means of dissolved air flotation, which thickens the material to $10 \%$ dry weight content $(100 \mathrm{~g} / \mathrm{L})$, are used as an initial step in dewatering to aggregate the microalgal cells and enhance the ease of further processing, such as sedimentation or centrifugal recovery (Grima et al. 2003). Gravity sedimentation, possibly enhanced by flocculation, is a separation technique with low energy demand and suitable for harvesting of large microalgae at reasonable cost, but it requires substantial area and that the downstream processes and product targets are tolerant to contamination by coagulants. The sediment sludge is more diluted than centrifugally recovered biomass, which substantially influences the economics of product recovery further downstream.

High-speed continuous centrifugation is definitely the preferred method for harvesting algal cells. It is used commercially, for example, to harvest high-value metabolites for hatcheries and nurseries in aquaculture, although strong gravitational and shear forces can damage the cell struc- 
Fig. 2: Flocculation of algae

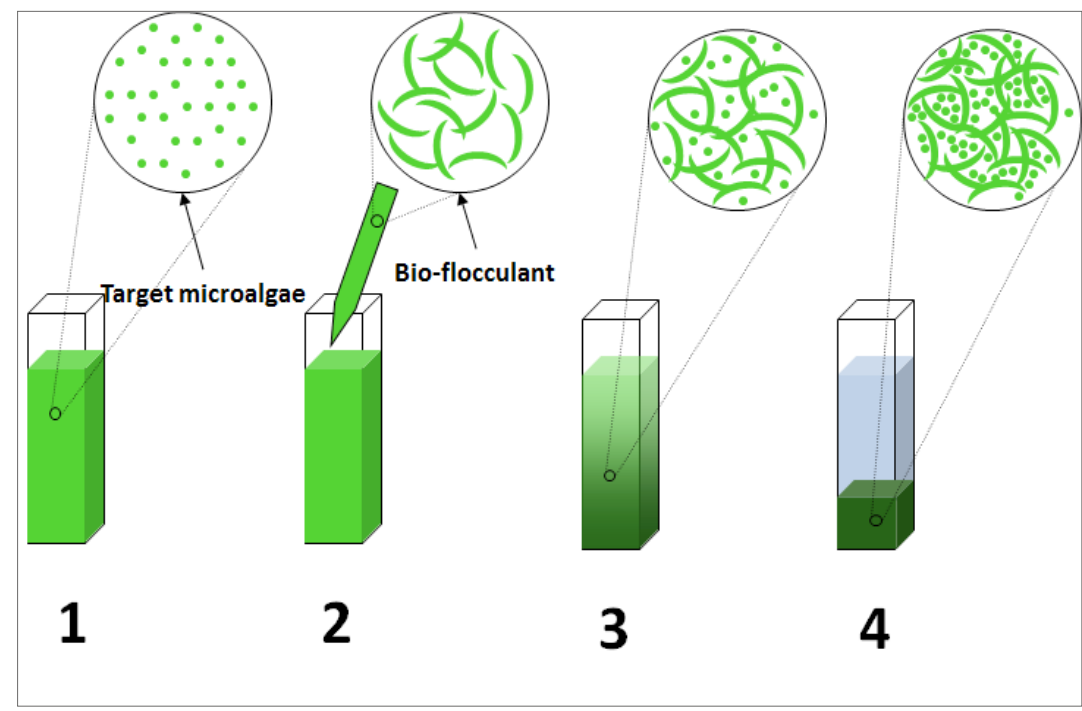

processing of algae for biofuels. Regardless of the harvesting method, it is essential to increase the biomass concentration in the reactor in order to reduce energy demand and costs for downstream processing. An increase to $1 \mathrm{wt} \%$ in a reactor compared to $0.1 \mathrm{wt} \%$ in a pond would decrease the amount of water to be processed to just $10 \%$, thereby also reducing the energy demand and downstream costs to $10 \%$.

Source: http://www.algae.wur.nl

ture (Heasman et al. 2000; Harun et al. 2010). The technique is yet not suitable for dewatering large volumes of algal suspension for the production of biofuels due to its high power consumption and costs (Molina et al. 2003).

Filtration using, for example, membrane, micro-, pressure, or vacuum filters has proved to be the most competitive harvesting option for large microalgae because of their mechanical simplicity and availability in large unit sizes, but is associated with extensive operation costs and hidden preconcentration requirements (Harun et al. 2010). To process low volumes $\left(<2 \mathrm{~m}^{3}\right.$ per day), membrane filtration can be more cost-effective than centrifugation. Owing to the cost of membrane replacement and pumping on larger scales of production ( $>20 \mathrm{~m}^{3}$ per day), centrifugation may be a more economical method of harvesting the biomass (MacKay, Salusbury 1988). The most common methods for drying large microalgae such as Chlorella, Scenedesmus, and Spirulina are spraydrying, drum-drying, freeze-drying, and sun-drying (Richmond 2004). The high water content of algal biomass means that sun-drying is not a very effective method for algal powder production, and spray-drying is not economically feasible for low value products such as biofuels.

Since the available separation devices are not economically feasible, harvesting and dewatering remain a major challenge to the industrial-scale

\section{How to Get the Lipids Out?}

Lipid extraction from microalgae represents another bottleneck hindering the economical industrial-scale production of algal biofuels. To produce biodiesel from oil seed, solvent extraction with hexane or ethanol is the preferred quick and efficient method of extraction (Richmond 2004). To extract microalgal lipids, only laboratory-scale technologies, but no methods for industrial-scale extraction, have been established, and the variables affecting lipid extraction are still not well understood (Brennan, Owende 2010; Halim et al. 2011). A paradigm controversy exists over the question if the dry or wet route is preferable for lipid extraction. In the dry route, the amount of energy required for dewatering the algal biomass is energetically prohibitive for production of algal biofuels (Halim et al. 2011). In the wet route, the energy required for the extraction of the oil is crucial (Xu et al. 2011).

Depending on the constitution of the cell wall and the desired product targets, either mechanical techniques, e.g. cell homogenizers, bead mills, autoclave, and spray drying, or non-mechanical methods, e.g. freezing, organic solvents and supercritical carbon dioxide, can be applied. Lipid extraction with supercritical carbon dioxide is a promising green technology that can potentially be used for large-scale 
microalgal lipid extraction. It is rapid, can replace expensive and toxic extraction chemicals (e.g. hexane), enables the sequential and selective extraction of different lipid classes (e.g. triacylglycerides, phospholipids), produces solvent-free lipids and high-quality biofuels, and increases overall efficiency (Soh, Zimmermann 2011; Xu et al. 2011). The carbon dioxide that was employed can be recycled after extraction or fed into the photobioreactors. The main disadvantages are the high capital cost and the large amount of energy required for supercritical fluid compression (Halim et al. 2012).

The extraction efficiency can be enhanced by pretreatment processes, such as disruption of the algal cells, facilitating the release of lipids and other intracellular metabolites. New pretreatment methods, such as ultrasound or microwave-assisted methods and pulsed electric field (PEF) treatment resulting in electroporation (EP) or electropermeabilization of the cell membrane, promise to improve the extraction efficiency and to lower costs compared with conventional methods (Cravotto et al. 2008; Göttel et al. 2012). In contrast to the existing commercial processes requiring cells to be harvested, concentrated, and destroyed so that the desired product can be extracted, live extraction (so-called milking of algae) might be an alternative harvesting technique (Hejazi, Wijffels 2004). This involves the continuous removal of secondary metabolites from cells, thereby enabling the biomass to be reused for the continuous production of high-value compounds. However, the milking mechanism and its relationship to stress factors are still not well understood, and the microalgal products that could be produced by the milking process are limited.

\section{With High-value Products to Algal Biofuels?}

The energy product range which can be derived from microalgae is tremendous, ranging from biofuel and jet fuel to alcohols and conventional liquid hydrocarbons, to pyrolysis oil and coke and to gaseous compounds such as methane and hydrogen. In the short run, algae to biogas conversion is promising because several key obstacles, i.e. dewatering and lipid extraction, can be overcome this way and the methane content of algal biogas can be $7-13 \%$ higher than that of biogas from maize silage (Mussgnug et al. 2010), but this depends strongly on the species and pretreatment. In the long run, hydrogen produced by Chlamydomonas reinhardtii switching from oxygen to hydrogen production under severe conditions may be attractive. The research focus and main investments of the private sector are neither on biogas nor on hydrogen but on liquid fuels for transportation (Schlagermann et al. 2012). From today's point of view the production costs for algal biofuels are far from competitive, but could theoretically be reduced to a range of 1.94 to $3.35 € / L$ of biodiesel if optimistic assumptions and biological and technological progress are taken into consideration (Delrue et al. 2012). To bridge the time gap
Fig. 3: Milestones of microalgal industry

\section{Milestones of Microalgal Industry}

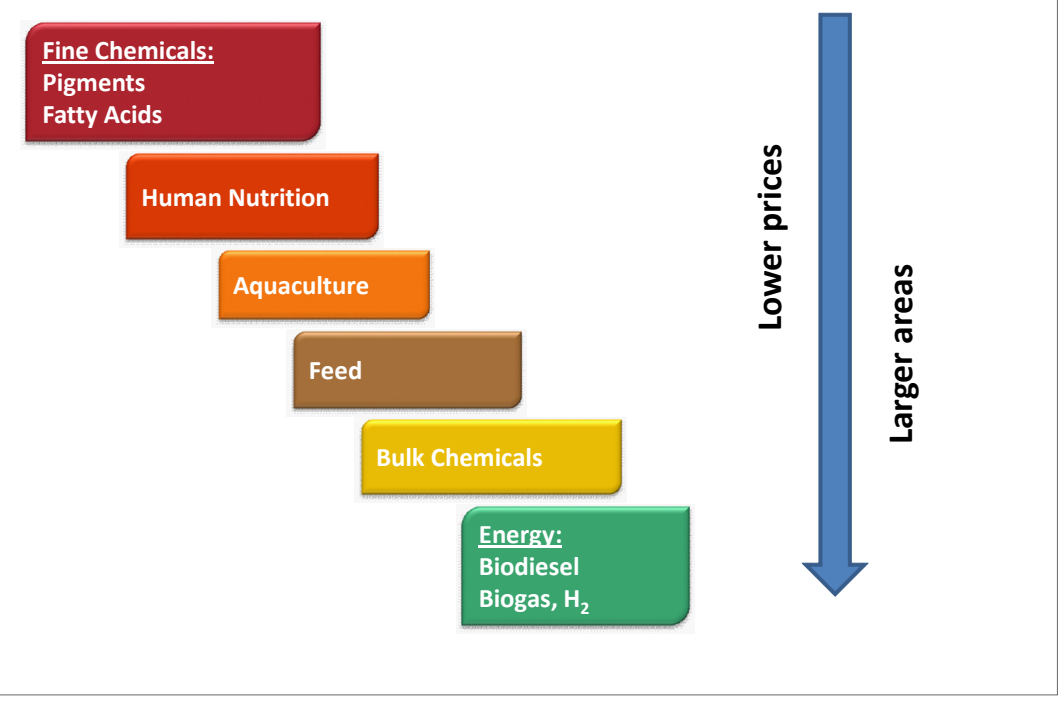

Source: Own compilation 
until algal biofuels become economically feasible and generate a cash flow for algae enterprises scaling up to meet the larger fuel market demands of tomorrow, markets for high-value products have to be entered because they can afford to employ energy- and labor-intensive production systems. In this way, the production of algal biofuels could benefit from the development of biotechnology for high-value production systems, e.g., in the form of more efficient cultivation systems and harvesting technologies and vice versa.

The range of algae-based high-value products for the food and feed market or chemical and pharmaceutical industries is broad, comprising polyunsaturated fatty acids, anti-oxidants, pigments, vitamins, polysaccharides, pharmaceutically active polyketides, antifouling agents to green chemicals, solvents, and biopolymers. Broadening the markets for these products and developing new algal products for human nutrition, animal feed, and the non-food fine chemical industry can act as milestones for the microalgal industry growth into the targeted biofuel market as illustrated in figure 3 .

The size and economic value of these and possibly new markets are ambiguous. Algae biomass is currently traded on commercial markets over a wide range of prices between $5 € / \mathrm{kg}$ for algal products and $50 € / \mathrm{kg}$ for high-value algaebased products. More than 10,000 dry tons of algae per year are produced worldwide for human and animal nutrition, in Japan, the USA, India, and China (Harmelen, Oonk 2006). The use of Chlorella, Spirulina, and Arthrospira for nutrition is limited to expensive health or food supplements sold in the form of tablets and capsules in the industrialized countries. Apart from this, the supply of algae proteins (e.g., Rubisco), of course without any taste or smell, could contribute to the fight against hunger and malnutrition in the world. Christophe Hug and Denis von der Weid outline in this issue the potential of the small-scale production of Spirulina to combat malnutrition in developing countries. They point out that support from large international organizations is a prerequisite for a wider implementation, which might be feasible if successful field trials accumulate evidence demonstrating the nutritious potential of Spirulina.
Microalgae feeds for aquaculture (aquafeeds) are currently produced in small amounts by hundreds of aquaculture operations and some commercial producers. These supply microalgae feeds, mainly fresh or as a refrigerated paste for bivalve, shrimp and fish fry, and fingerling production (Spolaore et al. 2006). However, the costs are high (100 €/kg of dry biomass), production systems are small, and the global production of aquafeeds currently amounts to approximately 1,000 tons (Muller-Feuga 2004). A large market for algal aquafeeds could be developed, replacing fish meal and oil, but production costs would have to be reduced to between 1 and $2 € / \mathrm{kg}$ of dry biomass.

The perspectives for algal products in animal feed production are promising in theory. This is a large and growing market, and protein is often the limiting ingredient in animal feed, so supplementing the feed with algal proteins could be advantageous. The composition of microalgae, in contrast to that of soybeans, illustrates their suitability as feed supplement (see table 2). It has been demonstrated that the incorporation of algae into poultry rations as a replacement for conventional proteins can reach a level of $5-10 \%$. According to estimates, about $30 \%$ of the current world algal production is already sold for animal feed applications (Becker 2007).

Table 2: Composition of microalgae in comparison to soybeans

\begin{tabular}{lrcr}
\hline & Oil & Protein & $\begin{array}{c}\text { Carbohy- } \\
\text { drate }\end{array}$ \\
\cline { 2 - 4 } & \multicolumn{3}{c}{$\%$ drywt } \\
\hline $\begin{array}{l}\text { Chlorella } \\
\text { vulgaris }\end{array}$ & $14-22$ & $51-58$ & $12-17$ \\
$\begin{array}{l}\text { Dunaliella salina } \\
\text { Spirulina }\end{array}$ & 6 & 57 & 32 \\
$\begin{array}{l}\text { maxima } \\
\text { Chlamydomonas } \\
\text { reinhardtii }\end{array}$ & $6-7$ & $60-71$ & $13-16$ \\
$\begin{array}{l}\text { Scenedesmus } \\
\text { obliquus }\end{array}$ & $12-14$ & $50-56$ & $10-17$ \\
\begin{tabular}{l} 
Soybeans \\
\hline
\end{tabular} & 20 & 48 & 30 \\
\hline
\end{tabular}

Source: Adapted from Chisti (2007) and Becker (2007) 
Robin J. Shields and Ingrid Lupatsch provide in this issue an overview of industry trends in the production of algal aquafuels and an outlook over future developments. They point out that the high costs of algal biomass compared to commodity feedstuffs currently confine their commercial use to niche animal feed applications such as aquaculture. Although the composition and digestibility of algae vary greatly between different strains and growing conditions, Shields and Lupatsch are optimistic that greater availability and lower prices would result in a more widespread use of algal feed in the future.

The product markets discussed separately as applications might suggest that each algal product market is on its own. This is, however, not the case, particularly if the aim is to enter high volume, low price markets such as biofuels. The costs of algae production can be covered more easily by a combined production that also includes highvalue streams. Although these may represent only a minor fraction of the total biomass, they contribute to the economic situation in a major way.
For example, the protein fraction of the residual algal biomass after lipid extraction could be used as a high-value feed supplement. The algae biorefinery concept provides for the coincident production of a spectrum of high-value products for the food, feed and chemical markets and low-value bulk energy products from algal biomass. Despite the opportunities opened by taking high-value coproduct markets as milestones to facilitate technology development and the commercialization of algal biofuels, it has to be remembered that the strongest driver for the development of large-scale algae technology is the hope that microalgae will one day make a remarkable contribution to meeting the world's energy needs.

\section{Are Economics the Roadblocks?}

The production costs of algal biofuels are much higher than those of traditional biofuels and have to be reduced by at least two orders of magnitude for microalgae to become a feasible source

\section{Fig. 4: Recycling of $\mathrm{CO}_{2}$ and nutrients by microalgae biomass production}

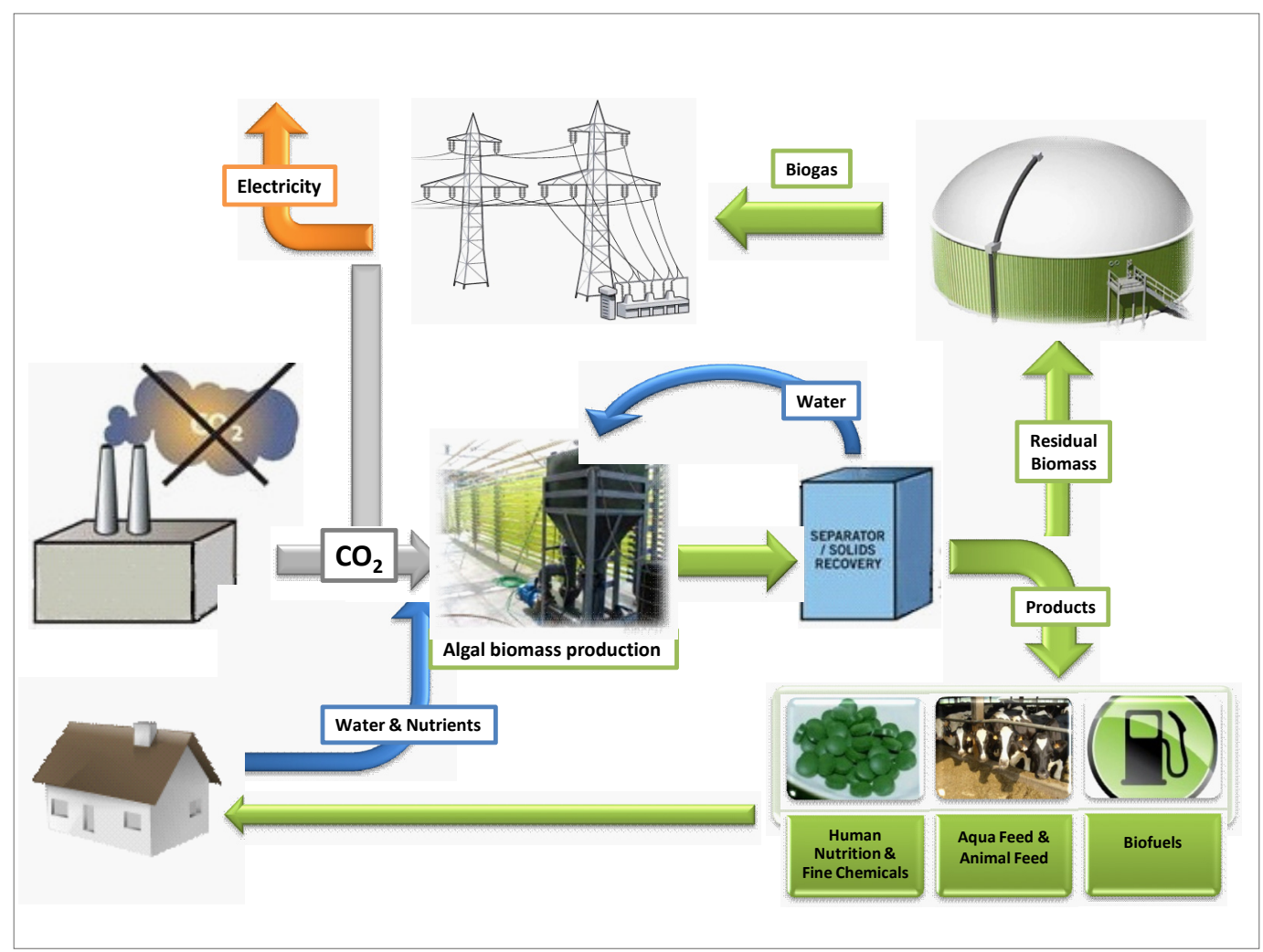

Source: Own compilation 
of biodiesel. Given that no large-scale process exists and a number of process steps have not even been demonstrated on an appreciable scale, the present cost estimates intrinsically include a relatively high degree of uncertainty in both the process steps and the costing methods. Moreover, there is potential for significant improvement in the future both from the opportunities for biological and engineering improvement and from room for capital cost reductions by establishing novel low-cost equipment for algae cultivation. Operating costs can be minimized further by employing a high degree of carbon and nutrient recycling as well as by assuming that waste water is delivered at low cost. The economic modeling of Niels-Henrik Norsker and colleagues in this issue shows that the development of reactors can in theory decrease the costs of microalgae cultivation in the longer-run (10-15 years) from the range of $2.40-3.20 € / \mathrm{kg}$ dry biomass (already possible today) to $0.68 € / \mathrm{kg}$ dry biomass. The economic feasibility of algal biofuels can be improved by the coproduction of high-value products. However, the market sustainability of such coproducts must be taken into consideration in the context of the envisioned commercial production volume. Considering the vast production quantities associated with the fuel market, it is not easy to find a valueadded coproduct on a comparable scale.

\section{Is Microalgae Production Sustainable?}

Biofuel production from microalgae is regarded to be more environmentally sustainable than from traditional energy crops. This appraisal is based on the fact that algae can be cultivated on nonarable land, improving land use efficiency. On the downside, several life cycle assessment studies indicate that the production of algal biomass is an extremely energy intensive process, making it difficult to come up with positive energy revenue (Lardon et al. 2009; Jorquera et al. 2010; Sander, Murthy 2010; Stephens et al. 2010; Collet et al. 2011). This is mainly due to the high energy demand for mixing, harvesting, dewatering, lipid extraction, and refining of the final product. Reducing mixing in photobioreactors can result in a positive net energy balance (see Niels-Henrik Norsker and colleagues in this issue).
The demand for nitrogen for growing microalgae contributes significantly to the energy demand since synthetic nitrogen fixation processes utilize fossil fuels, particularly natural gas. Tapping into existing nutritious agricultural or municipal waste streams can lower the fertilizer demand for nitrogen and phosphorous by $84 \%$ and $55 \%$ (Yang et al. 2011) and thus improve the energy balance and resource efficiency (Lardon et al. 2009). Waste streams, however, can introduce competitive native algae species, unacceptable pathogens, chemical compounds, or heavy metals into the system and hamper the selective enrichment of the algae species suitable for the production of high-lipid and high-value secondary metabolites. In addition, the use of nutritious waste streams to meet the fertilizer demand of large-scale microalgae plants would require concentration and transportation of the waste streams in a feasible way. Another approach to reduce nutrient demand is to pursue diligent recycling. The final fuel product from algal lipids does not contain any nitrogen and phosphorous; these nutrients end up primarily in the residual algal biomass. If the biomass residues are, for example, treated by anaerobic digestion or hydrothermal gasification, then most of the nutrients can be returned to the growth system at different stages of the algae processing (Rösch et al. 2012). The processes by means of which these nutrients are remobilized and made available for algal growth are yet not well understood.

The diffusion of $\mathrm{CO}_{2}$ from the atmosphere into microalgal cultures is not efficient enough to generate high biomass productivity due to the low $\mathrm{CO}_{2}$ content of air (380 ppmv $\mathrm{CO}_{2}$ ) and the high surface tension of water. The utilization of $\mathrm{CO}_{2}$ emitted by industrial and fossil fuel power plants $\left(5-6 \% \mathrm{CO}_{2}\right.$ from the combustion of natural gas and $10-15 \% \mathrm{CO}_{2}$ from coal burning (Fishmann et al. 2010) can improve the performance of algal fuel production (Kumar et al. 2010), especially when the combustion plants are close to the microalgae cultivation site or can be connected economically via $\mathrm{CO}_{2}$ pipelines and carbon credits can be earned (fig. 4) since 1.3-2.4 $\mathrm{kg} \mathrm{CO}_{2}$ is required per $\mathrm{kg}$ of dry algae (based on 36 to $65 \%$ $\mathrm{C}$ content of dry algae) and prices for commercially delivered $\mathrm{CO}_{2}$ are in the range of 30 to $45 €$ per ton of $\mathrm{CO}_{2}$ (Becker 2008). Flue gases, how- 
ever, contain several chemical compounds (e.g. $\mathrm{SO}_{2}$ and $\mathrm{NO}_{\mathrm{x}}$ ) that - even at concentration levels of flue gas treated to current emission threshold values - can affect the growth, biochemical composition and excretion of microalgae or are even toxic for microalgae (Hende et al. 2012). Yet some microalgae strains have been found that are tolerant to even high levels of $\mathrm{SO}_{\mathrm{x}}$ and $\mathrm{NO}_{\mathrm{x}}$ (Sydney et al. 2010; Yoo et al. 2010). The use of flue gas emissions should be given detailed consideration since the quality of the flue gas might hamper specific applications in the high-value coproduct markets. The large areas of land, favorable climate, and ample water supplies that are needed will also restrict the $\mathrm{CO}_{2}$ recycling potential of microalgae.

The cultivation of microalgae takes places in aquatic systems, and the large-scale production of algal biomass will consume large volumes of water. In warm climates, microalgae production in open ponds can have a huge water footprint (Subhadra, Edwards 2011). In contrast, closed photobioreactors that are highly efficient in recycling water generate only a small water footprint. Depending on the algal strain, the harvesting and dewatering processes, and the product targets, the amount of water that can be recycled can be limited, however, by the accumulated salts, chemical flocculants used for harvesting, or biological inhibitors produced by the strains themselves that could impair growth. Furthermore, it has to be taken into consideration that an enormous culture volume has to be pumped and processed daily due to the rapid growth of microalgae. Moving such large volumes of water is energy intensive and can impose a significant cost.

One of the main paradigms of microalgae production is that algae can be cultivated on non-arable land, thus avoiding land use competition with food production. The availability of non-arable or marginal land not used for agricultural production is however limited, especially in areas where the climatic conditions (radiation, temperature) and topography are suitable as well as where there is access to water, waste nutrients and a supply of carbon from flue gas emission. Johannes Skarka presents in this issue a GISbased model for selecting algae production sites and evaluating resources. His calculations for Europe indicate that the restriction of algae pro- duction to non-arable land will keep the annual energy potential in the range of $1 \mathrm{EJ}$. This amount is small compared to the technical potential of terrestrial biomass in Europe, estimated to 8.9 EJ (Thrän, Kaltschmitt 2002), but it brings added value to areas of otherwise no commercial value. The estimated annual production potential for microalgae on marginal land in China is thought to be an order of magnitude higher, namely 4.19 billion standard coal equivalents, far more than the total annual energy consumption equivalent in China in 2007 (Zhang et al. 2012).

Assessing the overall sustainability of algal biofuel production goes far beyond energy and mass balances and the calculation of land and water footprints. Christine Rösch and Daniel Maga present in this issue a methodological approach for a systematic and well-structured analysis of different aspects of sustainability. The application of sustainability criteria and indicators contributes to identifying sustainability challenges that will probably have to be surmounted for microalgae production technologies and systems to produce algal biofuels and high-value products in an economically viable and environmentally sound way.

\section{What's Next?}

Microalgae represent one of the most challenging and promising new sources of biomass, but longterm basic and applied research and development are required to develop this technology to make it commercially viable and fully sustainable. Basic research and development will also contribute to expanding our theoretical knowledge and the deployment potential of microalgae for biofuel production. Although there is great hope that the required technological development is feasible, some are of the opinion that the application of microalgae is only viable in niche markets and that algal biofuels are just hype. The reason for this divergent view is that our background knowledge and understanding of algae's biology is little established. Various specialists such as biologists and technical engineers are involved, and their close collaboration is essential for the creation of innovative solutions. The articles in this issue reflect the multifaceted nature and complexity of the development of microalgae technology. 
Hopefully they can provide the fundamental orientation for non-expert readers from the technology assessment community and impulses for those who are more familiar with the issue.

Currently, many conceptual aspects are unclear, and a stepwise approach is needed in research and investment. Normative settings coming from the debate about sustainability can act as plausible crash barriers for a roadmap towards generating biofuels from microalgae and provide the societal framework for the next necessary steps of innovative research. If large-scale microalgae cultivation later turns out to be the best solution, their effects on social acceptance and the landscape in general will also have to be a topic for discussion. The issue of centralized and decentralized microalgae production and the mode of transportation of the production resources and of the expected high-quality products to the consumers will exert a strong influence on social acceptability. The ecological aspects of the construction and operation of microalgae plants and the required infrastructures could also be important, such as the utilization of water and waste streams as sources of nutrients. Once the theoretical framework and the development of initial prototypes has been finished, classical technology assessment can start to generate systematic knowledge of the intended effects and unintended side effects of algae biotechnology for biofuel production.

\section{Note}

1) The editors of this thematic focus and the editorial team of TATuP are grateful for the always constructive assistance of Alison Hepper and Michael Wilson, who did the linguistic revision of the English manuscripts with great care and commitment.

\section{References}

Becker, E.W., 2007: Microalgae as a Source of Protein. In: Biotechnology Advances 25/2 (2007), pp. 207-210

Becker. E.W., 2008: Microalgae: Biotechnology and Microbiology. Cambridge (Cambridge Studies in Microbiology, Vol. 10)

Benemann, J.R., 1997: CO Mitigation with Microalgae Systems. In: Energy Conversion and Management 38 (1997), pp. S475-S479
Borowitzka, M.A., 1999: Commercial Production of Microalgae: Ponds, Tanks, Tubes and Fermenters. In: Journal of Biotechnology 70/1-3 (1999), pp. 313-321 Brennan, L.; Owende, P., 2010: Biofuels from Microalgae - A Review of Technologies for Production, Processing, and Extractions of Biofuels and Co-products. In: Renewable and Sustainable Energy Reviews 14/2 (2010), pp. 557-577

Chisti, Y., 2007: Biodiesel from Microalgae. In: Biotechnology Advances 25 (2007), pp. 294-306

Collet, P.; Hélias, A.; Lardon, L. et al., 2011: Lifecycle Assessment of Microalgae Culture Coupled to Biogas Production. In: Bioresource Technology 102/1 (2011), pp. 207-214

Cravotto, G.; Boffa, L.; Mantegna, S. et al., 2008: Improved Extraction of Vegetable Oils under Highintensity Ultrasound and/or Microwaves. In: Ultrasonics Sonochemistry 15/5 (2008), pp. 898-902

Delrue, F.; Setier, P.-A.; Sahut, C. et al., 2012: An Economic, Sustainability, and Energetic Model of Biodiesel Production from Microalgae. In: Bioresource Technology 111 (2012), pp. 191-200

Fishman, D.; Majumdar, R.; Morello, J. et al., 2010: National Algal Biofuels Technology Roadmapp. A Technology Roadmap Resulting from the National Algal Biofuels Workshop December 9-10, 2008, College Park, Maryland

Göttel, M.; Eing, Ch.; Gusbeth, Ch. et al., 2012: Pulsed Electric Field Treatment of Microalgae for Cell Ingredients Extraction. Karlsruhe Institute of Technology (KIT), Institute for Pulsed Power and Microwave Technology (IHM), Karlsruhe

Grima, M.E.; Belarbi, E.H.; Fernandez, F.G.A. et al., 2003: Recovery of Microalgal Biomass and Metabolites: Process Options and Economics. In: Biotechnology Advances 20/7-8 (2003), pp. 491-515

Halim, R.; Danquah, M.K.; Webley, P.A., 2012: Extraction of Oil from Microalgae for Biodiesel Production: A Review. In: Biotechnology Advances 30/3 (2012), pp. 709-732

Halim, R.; Gladman, B.; Danquah, M.K. et al., 2011: Oil Extraction from Microalgae for Biodiesel Production. In: Bioresource Technology 102/1 (2011), pp. 178-185

Harmelen, T. van, Oonk, H., 2006: Microalgae Biofixation Processes: Applications and Potential Contributions to Greenhouse Gas Mitigation Options. Report, International Network on Biofixation of $\mathrm{CO}_{2}$ and Greenhouse Gas Abatement. The Netherlands

Harun, R.; Singh, M.; Forde, G.M. et al., 2010: Bioprocess Engineering of Microalgae to Produce a Va- 
riety of Consumer Products. In: Renewable and Sustainable Energy Reviews 14/3 (2010), pp. 1037-1047

Heasman, M.; Diemar, J.; O'Connor, W. et al., 2000: Development of Extended Shelf-life Microalgae Concentrate Diets Harvested by Centrifugation for Bivalve Molluscs - A Summary. In: Aquaculture Research 31/8-9 (2000), pp. 637-59

Hejazi, M.A.; Wijffels, R.H., 2004: Milking of Microalgae. In: Trends in Biotechnology 22/4 (2004), pp. 189-194

Hende, S. van den; Vervaeren, H.; Boon, N., 2012: Flue Gas Compounds and Microalgae: (Bio-)chemical Interactions Leading to Biotechnological Opportunities. In: Biotechnology Advances, in press

Jorquera, O.; Kiperstok, A.; Sales, E.A. et al., 2010: Comparative Energy Life-cycle Analyses of Microalgal Biomass Production in Open Ponds and Photobioreactors. In: Bioresource Technology 101 (2010), pp. 1406-1413

Kumar, A.; Ergas, S.; Yuan, X. et al., 2010: Enhanced $\mathrm{CO}_{2}$ Fixation and Biofuel Production via Microalgae: Recent Developments and Future Directions. In: Trends in Biotechnology (2010), pp. 371-380

Lardon, L.; Hélias, A.; Sialve, B. et al., 2009: LifeCycle Assessment of Biodiesel Production from Microalgae. In: Environmental Science \& Technology 43/17 (2009), pp. 6475-6481

MacKay, D.; Salusbury, T., 1988: Choosing Between Centrifugation and Crossflow Microfiltration. In: Chemical Engineering Journal 477 (1988), pp. 45-50

Molina Grima, E.; Belarbi, E.H.; Acien Fernandez, F.G. et al., 2003: Recovery of Microalgal Biomass and Metabolites: Process Options and Economics. In: Biotechnology Advances 20/7-8 (2003), pp. 491-515

Morweiser, M.; Kruse, O.; Hankamer, B. et al., 2010: Developments and Perspectives of Photobioreactors for Biofuel Production. In: Applied Microbiology and Biotechnology 87/4 (2010), pp. 1291-1301

Muller-Feuga, A., 2004: Microalgae for Aquaculture: The Current Global Situation Future Trends. In: Richmond, A. (ed.): Handbook of Microalgal Culture: Biotechnology and Applied Phycology. Oxford, UK, pp. 352-364

Mussgnug, J.H.; Klassen, V.; Schlüter, A. et al., 2010: Microalgae as Substrates for Fermentative Biogas Production in a Combined Biorefinery Concept. In: Journal of Biotechnology 150/1 (2010), pp. 51-56

Radakovits, R.; Jinkerson, R.E.; Darzins, A. et al., 2010: Genetic Engineering of Algae for Enhanced Biofuel Production. In: Eukaryot Cell 9 (2010), pp. 486-501
Richmond, A. (ed.), 2004: Handbook of Microalgal Culture: Biotechnology and Applied Phycology. Oxford

Rodolfi, L.; Zittelli, G.C.; Bassi, N. et al., 2009: Microalgae for Oil: Strain Selection, Induction of Lipid Synthesis and Outdoor Mass Cultivation in a Lowcost Photobioreactor. In: Biotechnology and Bioengineering102 (2009), pp. 100-112

Rösch, Chr.; Skarka, J.; Wegerer, N., 2012: Materials Flow Modeling of Nutrient Recycling in Biodiesel Production from Microalgae. In: Bioresource Technology 107 (2012), pp. 191-197

Sander, K.; Murthy, G.S., 2010: Life Cycle Analysis of Algae Biodiesel. In: International Journal of Life Cycle Assessment 15/7 (2010), pp. 704-714

Schlagermann, P.P.; Göttlicher, G.; Dillschneider, R. et al., 2012/ in press: Composition of Algae Oils and its Potential as Biofuel. In: Journal of combustion

Schuhmann, H.; Lim, D.K.Y.; Schenk, P.M., 2012: Perspectives on Metabolic Engineering for Increased Lipid Contents in Microalgae. In: Biofuels 3 (2012), pp. 71-86

Sheehan, J.; Dunahay, T.; Benemann, J. et al., 1998: A Look Back at the U.S. Department of Energy's Aquatic Species Program: Biodiesel from Algae. U.S. Department of Energy's Office of Fuels Development

Soh, L.; Zimmerman, J., 2011: Biodiesel Production: The Potential of Algal Lipids Extracted with Supercritical Carbon Dioxide. In: Green Chemistry 13/6 (2011), pp. 1422-1429

Spolaore, P.P.; Joannis-Cassan, C.; Duran, E. et al., 2006: Commercial Applications of Microalgae. In: Journal of Bioscience and Bioengineering 101/2 (2006), pp. 87-96

Stephens, E.; Ross, I.L.; King, Z. et al., B., 2010: An Economic and Technical Evaluation of Microalgal Biofuels. In: Nature Biotechnology 28/2 (2010), pp. 126-128

Subhadra, B.G.; Edwards, M., 2011: Coproduct market analysis and water footprint of simulated commercial algal biorefineries. In: Applied Energy 88/10 (2011), pp. 3515-3523

Sydney, E.B.; Sturm, W.; de Carvalho, J.C. et al., 2010: Potential Carbon Dioxide Fixation by Industrially Important Microalgae. In: Bioresource Technology 101 (2010), pp. 5892-5896

TFZ - Technologieforschungszentrum Bayern, 2012: Raps - die Ölpflanze unserer Breiten. Anbau, Erträge, Ausweitungspotenzial; http://www.tfz.bayern.de/ sonstiges/16459/07brs036_raps_die_oelpflanze_unserer_breiten.pdf(download 10.4.12) 
Thrän D.; Kaltschmitt M., 2002: Biomass for a Sustainable Energy Provision Systems - State of Technology, Potentials and Environmental Aspects. In: Sayigh, A. (ed.): Workshop Proceedings. World Renewable Energy Congress, June 29-July 5, 2002. Cologne, Germany 2002

Tredici, M.R., 2010: Photobiology of Microalgae Mass Cultures: Understanding the Tools for the Next Green Revolution. In: Biofuels 1/1 (2010), pp. 143-162

Xu, L.; Brilman, D.W.F.; Withag, J.A.M. et al., 2011: Assessment of a Dry and a Wet Route for the Production of Biofuels from Microalgae: Energy Balance Analysis. In: Bioresource Technology 102/8 (2011), pp. 5113-5122

Yang, J.; Xu, M.; Zhang, X. et al., 2011: Life-cycle Analysis on Biodiesel Production from Microalgae: Water Footprint and Nutrients Balance

Zhang, Q.; Ma, J.; Qiu, G. et al., 2012: Potential Energy Production from Algae on Marginal Land in China. In: Bioresource Technology 109 (2012), pp. 252-260

\section{Contact}

Dr. Christine Rösch

Karlsruhe Institute of Technology (KIT)

Institute for Technology Assessment and

Systems Analysis (ITAS)

Karlstraße 11, 76133 Karlsruhe

Phone: +49 (0) 721 / 608 - 22704

E-mail: christine.roesch@kit.edu

《〉

\section{Algae as an Approach to Combat Malnutrition in Developing Countries}

\author{
by Christophe Hug and Denis von der Weid, \\ Antenna Technologies Foundation ${ }^{1+2}$
}

Algae are being increasingly used in our food. Their use is, however, not an entirely new phenomenon as some species have been beneficially consumed in diverse cultures for centuries. Algae's wealth of nutrients has also led researchers to investigate new approaches for combating malnutrition in developing countries. One approach is based on the smallscale production of the microalga "Spirulina" and has proved to have considerable potential as a tool for development. Significant work has been done to develop its production and distribution in order to reach malnourished populations. However, although this approach has been successful, support for it by large international organisations is weak, and they do not include it in their development efforts. This might nevertheless change as evidence is accumulated in successful field trials.

\section{Algae in Human Food}

For centuries, coastal populations have taken advantage of the availability of algae to supplement their food supply, also using it as fertilizer and as animal feed. Traces of algae have been found in the ashes of prehistoric dwellings, which suggests that mankind turned to algae as a source of sustenance at an early time. Algae have been a traditional and timeless food source in the coastal regions of East Asia. In Japan, China and Korea, for instance, they are well anchored in food habits, and their daily consumption keeps algae farms busy. In North America and Europe, consumption is more limited and recent, where production is largely limited to the field of extracted by-products such as alginates and agars. These are used as food additives in a variety of food products for their gelling or thickening properties. However, research is zooming ahead into using algae to develop novel food products, taking advantage of the fact that the functionality of 